\title{
KONTRIBUSIPSIKOLOGIRADIKAL FRANTZ FANON DALAM PENDAMPINGAN KOREAN KONFLIK SOSIAL DIPOSO
}

\author{
GEORGE JUNUS ADITJONDRO, Ph.D. \\ (konsultan Yayasan Tanah Merdeka, Palu; \\ konsultan UPKM/CD RS Bethesda, Yogyakarta)
}

\begin{abstract}
Abstrak
Tulisan ini bertujuan untuk menggunakan teori Psiko Analisi Franzt Fanon untuk menganalisis pergolakan kejiwaan masyarakat korban konflik sosial di Poso. Sejauh ini program re-healing untuk masyarakat korban konflik sosial dengan menggunakan pendekatan psiko-sosial dan ekonomi hanya bersifat karitatif dan menimbulkan ketergantungan. Psikologi radikal Frantz Fanon, menawarkan suatu pendekatan yang lebih menyeluruh, tanpa mengawetkan ketergantungan masyarakat korban pada badan-badan bantuan.
\end{abstract}

\section{A. Pengantar}

Berbagai konflik sosial di Indonesia pasca-Soeharto telah meninggalkan ratusan ribu jiwa terdampar sebagai pengungsi, atau yang secara intemasional biasa disebut internally displaced peoples (IDPs). Kehadiran ratusan ribu pengungsi itu, selain menjadi lahan basah bagi para birokrat dan kontraktor Departemen Kesejahteraan Sosial (Depsos), juga melahirkan sejumlah besar organisasi non-pemerintah (omop) atau lembaga pengembang swadaya masyarakat (LPSM) yang mengkhususkan diri pada pendampingan para pengungsi domestik tersebut. Dilihat dari pendekatannya, sebagian besar LPSM itu mengfokuskan diri pada penyembuhan trauma yang diidap para pengungsi, serta dampak psikososial yang lain. Pendekatan dalam pendampingan pengungsi ini sangat berkembang, berkat dukungan dana dari lembaga-lembaga dana intemasional dan nasional.

Sementara itu, segelintir ornop belakangan ini mulai mengfokuskan diri pada faktor-faktor ekonomi-politik yang ikut melatarbelakangi - atau 
melestarikan - konflik sosial yang melanggengkan keberadaan para pengungsi itu. Mereka berusaha mengungkapkan kepentingan-kepentingan apa yang ada di balik pelestarian konflik di Poso dan kabupaten hasil pemekarannya yang pertama, Morowali.

Polarisasi antara kedua pendekatan itu menunjukkan suatu masalah epistomologi yang lebih mendalam, yakni kesenjangan (gap) antara psikologi - khususnya psikologi sosial - dan ilmu politik - khususnya ekonomi politik - dalam pendampingan para korban konflik sosial. Menurut hemat penulis, kesenjangan itu dapat diatasi apabila para pekerja sosial dan aktivis ornop yang bekerja di lingkungan pengungsi, atau bekerja untuk menggali akar-akar permasalahan yang melahirkan arus pengungsi, lebih mengenal perspektif Frantz Fanon (1925-1961), psikologi kulit hitam asal Kepulauan Martinique di Laut Karibia, yang telah memadukan pendekatan psikologi - khususnya psikiatri - dengan pendekatan ilmu politik.

\section{B. Psikologi Radikal Frantz Fanon}

Siapa itu Frantz Fanon, dan apa karakteristik psikologi radikalnya? Barangkali, Fanon lebih dikenal dalam literatur ilmu politik dan sosiologi politik, khususnya dalam literatur tentang perjuangan-perjuangan kemerdekaan bangsa-bangsa jajahan Eropa di Dunia Ketiga. Khususnya lagi dalam literatur tentang perjuangan kemerdekaan bangsa-bangsa Afrika, karena keterlibatan Fanon dalam perjuangan kemerdekaan Aljazair, sebagai jurubicara FLN (Front Pembebasan Nasional) dari tahun 1956 s/d 1961 (lihat Aditjondro 2000).

Namun sesungguhnya, karier Fanon dimulai sebagai psikiater di klinik Blida-Joinville, di musim gugur 1953. Kesempatan itu dimanfaatkannya untuk menerapkan metode-metode psikiatri yang telah dikembangkannya bersama gurunya, Professor Francois Tosquelles. Misalnya, penggunaan terapi lingkungan, yang mempertimbangkan faktor-faktor lingkungan sosial dan interpersonal yang mempengaruhi para pasien. Tapi yang terpenting, selama masa tugas di Blida-Joinville, Aljazair, Fanon menemukan, bahwa terapi yang dikembangkan di Eropa untuk pasien-pasien kulit putih, tidak tepat untuk diterapkan terhadap pasien-pasien Aljazair. Selain itu, ia semakin memperdalam pengamatannya terhadap dampak perang dan kekerasan terhadap jiwa para pasien, yang sudah dimulainya selama bertugas di klinik Saint Alban di Perancis (Gendzier 1974: 61-71). 
Pengamatannya di berbagai klinik Saint Alban dan di Blida-Joinville, diteruskannya ketika ia mengepalai Dinas Kesehatan FLN di basis para gerilyawan perjuangan kemerdekaan Aljazair di negara tetangga, Tunisia. Berbagai kasus yang telah ditangani dan diamatinya itu dituangkannya dalam Bab 5 bukunya yang termasyhur tentang perjuangan kemerdekaan bangs-bangsa dan kelompok-kelompok etnis yang tertindas, Les Damnes de la Terre.

Dalam buku yang pertama kali diterbitkan di Perancis setelah ia meninggal di sebuah rumah sakit di AS, tanggal 6 Desember 1961, berbagai kasus gangguan jiwa - baik yang diderita oleh pasien Aljazair dan pasien Perancis, laki maupun perempuan, orang dewasa maupun pemuda dibeberkan. Berbagai kasus itu ditempatkan dalam konteks perang kemerdekaan. Konteks sosial yang selalu jadi bahan pertimbangan utama dalam psiko-analisa Fanon. Salah satu kasus yang menarik, adalah impotensi yang diderita oleh seorang pejuang Aljazair yang isterinya diperkosa oleh tentara Perancis (lihat Fanon 1971: 204-8). Kasus lain adalah bagaimana seorang inspektur polisi Perancis menyiksa isteri dan anak-anaknya, akibat stress yang dideritanya karena sering menyiksa tahanan-tahanan Aljazair (Fanon 1971: 215-7).

Sebelumnya, bertolak belakang dengan psiko-analisis Freud yang biasa menafsirkan mimpi sebagai gejala individual yang erat kaitannya dengan urusan seksual, Fanon menafsirkan mimpi para pasien yang disampaikan di sofa psikiatri dalam konteks relasi kekuasaan penjajah versus terjajah (Aljazair versus Perancis) dan laki-laki versus perempuan. Penjungkirbalikan psiko-analisis Freud dengan kontekstualisasi politiknya dilakukan juga oleh Fanon terhadap tafsiran mimpi-mimpi orang Malagasi dalam karya Octave Mannoni tentang psikologi penjajahan di Malagasi (Madagaskar).

Ketujuh mimpi orang Malagasi sarat dengan tema teror. Tema itu ada yang diwakili oleh banteng hitam; ada yang diwakili oleh laki-laki hitam; tentara Senegal lengkap dengan senapan mereka; serta bayang-bayang yang seram. Bertolak belakang dengan psiko-analisis Freud, Fanon menolak penafsiran banteng-banteng hitam sebagai symbol dari phallus. Begitu pula senapan yang ditodongkan oleh para serdadu Senegal dalam mimpi Razafi, seorang pemuda berumur 14 tahun, yang juga mendengar suara tapak kaki kuda yang berlari. Sementara Mannoni menafsirkan mimpi pemuda itu sebagai ekspresi keterkejutan mendengar dan melihat ibunya disetubuhi oleh ayahnya, Fanon menafsirkan mimpi Razafi sebagai ekspresi ketakutan 
pemuda itu pada serdadu-serdadu Senegal. Serdadu-serdadu berkulit hitam itu direkrut oleh penguasa kolonial Perancis untuk mengamankan jajahanjajahannya di Afrika Utara. Senapan itu adalah senapan benaran, model Lebel 1916, begitu menurut Fanon (Mannoni 1990: 90-91; Fanon 1973: 283).

Menyimpulkan dasar pemikiran yang melatarbelakangi penafsirannya, Fanon mengutip Pierre Naville dalam buku Psychologie. Marxisme. Materialisme (Paris: Marcel Riviere, 1948: 151):

To speak of society's dreams as one speaks of the dreams of the individual, to discuss collective will to power as one discusses individual sexual drive, is to reverse the natural order of things once more, because, on the contrary, it is the economic and social conditions of class conflicts that explain and determine the real conditions in which individual sexuality expresses itself, and because the content of a human being's dreams depends also, in the last analysis, on the general conditions of the culture in which he lives, (dikutip dalam Fanon 1973: 282-283).

Jadi kalau boleh saya simpulkan, Fanon tidak sekedar memanfaatkan mimpi-mimpi kliennya sebagai jendela untuk melihat pergumulan kejiwaan mereka dengan lingkungan terdekatnya dan gairah seksual yang tidak tersalur secara sempurna. Sebaliknya, Fanon melihat mimpi-mimpi para penderita gangguan kejiwaan sebagai 'jendela' untuk melihat ketertindasan yang dirasakan oleh para klien dengan struktur ekonomi dan politik di mana ia berada. Misalnya, mimpi seorang buruh lelaki yang ingin menyetubuhi isteri majikannya bukan sebagai tanda libido sang buruh yang tidak tersalur, tapi, dalam masyarakat yang patriarkis, sebagai balas dendam sang buruh terhadap majikannya, yang memeras tenaganya habis-habisan tanpa imbalan yang sepadan.

Mirip mimpi buruh pabrik itu, di tahun-tahun pertama perlawanan terhadap rezim Soeharto, seorang aktivis mahasiswa menceritakan anganangannya kepada saya untuk memperkosa Nyonya Tien Soeharto. Dalam kerangka psiko-analisis Fanon, angan-angan itu bukan karena figur Ibu Negara itu membangkitkan gairah seksual sang aktivis. Angan-angan itu lebih merupakan ekspresi kemarahan sang aktivis terhadap otoriterisme Soeharto, yang mengizinkan isterinya melakukan intervensi ke dalam pemerintahannya, dengan secara langsung memerintahkan para gubernur menyetorkan dana dan sumber daya alam mereka untuk pembangunan 
Taman Mini Indonesia Indah (TMII), tahun 1971 (lihat Elson 2001: 198199).

\section{Kesenjangan antara pendekatan Psiko Sosial dan pendekatan Ekonomi Politik dalam pendampingan korban di Poso}

Sejak pecahnya kerusuhan Poso di bulan Desember 1998, berbagai ornop dari dalam dan luar negeri, berkiprah di Kabupaten Poso untuk membantu para pengungsi dan korban kerusuhan yang tidak mengungsi. Selain bergerak dalam bidang-bidang teknis, seperti pembangunan kembali rumah berikut prasarana air minum dan jamban keluarga, ornop-ornop itu juga berusaha aktif melakukan rekonsiliasi di antara komunitas Muslim dan Nasrani yang dulu angkat senjata di Kabupaten Poso, sebelum perjanjian perdamaian ditandatangani di Malino di bulan Desember 2001.

Kegiatan-kegiatan di bawah bendera "rekonsiliasi konflik" ini mendapat dukungan dari semua badan resmi, mulai dari Departemen Kesejahteraan Sosial, Universitas Tadulako, United Nations Development Programme (UNDP) yang bernaung di bawah Perserikatan Bangsa-Bangsa (PBB), serta sejumlah lembaga dana internasional. Namun program kerja yang kini bernaung di bawah payung "peace building " ini, hanya terbatas pada pengungkapan dan penanganan faktor-faktor psiko-sosial (lihat skema terampir), tanpa berusaha menggali lebih mendalam akar-akar permasalahan yang lebih mendalam.

Sementara itu, segelintir ornop serta organisasi yang didirikan oleh para pengungsi dan mantan combatant, belakangan ini mulai mengfokuskan diri pada faktor-faktor ekonomi-politik yang ikut melatarbelakangi - atau melestarikan - konflik sosial yang melanggengkan .keberadaan para pengungsi itu (lihat skema terlampir). Hasil investiga'si ini menunjukkan dominannya kepentingan "industri pengungsi" yang telah memperkaya sekian banyak birokrat dan aparat keamanan, dari tingkat kabupaten sampai ke tingkat pemerintah pusat (lihat YTM 2005).

Selain itu, berbagai satuan dan tingkatan aparat keamanan - TNI dan Polri - juga diuntungkan oleh citra ketidakamanan di Kabupaten Poso dan Kabupaten Morowali, tetangganya. Pada gilirannya, investor-investor besar yang muncul untuk mengolah sumber daya alam di Kabupaten Morowali dan tetangganya, Kabupaten Banggai, terutama kelompok Medco milik Arifin Panigoro dan kelompok Artha Graha milik TNI/AD dan Tomy Winata,

KONTRIBUSI PSIKOLOGI RADIKAL FRANTZ FANON 
juga diuntungkan oleh eskalasi penempatan pasukan di kabupatenkabupaten di sebelah timur Poso itu (lihat Aditjondro 2004a, 2004b).

Untuk diketahui, kasus bom di Pasar Tentena baru-baru ini juga tidak terlepas dari kepentingan modal besar dan serdadu pelindungnya. Tidak lama setelah kejadian bom itu, penguasa desa Saojo dekat Tentena didekati oleh aparat TNI/AD, untuk mendapatkan tanah buat pembangunan satu kompi lagi, selain markas-markas batalyon dan kompi TNI yang sedang dibangun dekat kota Poso dan Pendolo (Kec. Pamona Selatan). Keberadaan satu kompi tambahan di Saojo tentunya tidak terlepas dari kehadiran proyek PLTAdi Desa Sulewana, dekat Saojo. PLTA Sulewana itu sedang dibangun oleh kelompok Bukaka milik keluarga Jusuf Kalla, kini Wakil Presiden Indonesia.

Pendekatan ekonomi politik ini, tidak begitu populer di kalangan lembaga-lembaga resmi pemerintah di Sulawesi Tengah, yang didukung oleh lembaga intemasional yang bernaung di bawah PBB, seperti UNDP, maupun oleh lembaga-lembaga dana intemasional. Berbagai lembaga ini hanya bersedia membiayai pengungkapan faktor-faktor psiko-sosial, dengan menafikan faktor-faktor ekonomi politik. Terbukti dari oposisi UNDP terhadap Lembaga Pemberdayaan Masyarakat Sipil (LPMS) di Poso, sebuah ornop penerima hibah UNDP, yang telah melebarkan sayapnya dari pendampingan psiko-sosial ke kampanye anti korupsi yang dianggap terlalu "politis".

Itu hanyalah salah satu bentuk oposisi dari jejaring korupsi dana bantuan pengungsi, terhadap para aktivis anti korupsi dana bantuan pengungsi di Sulawesi Tengah. Ada yang kantomya diteror dengan bom, pemimpinnya digugat oleh Pjs. Bupati dengan tuduhan mencemarkan nama baiknya, sampai dengan teror telepon dan sms.

\section{Integrasi ala Fanon dalam pendampingan korban konflik di Poso}

Apa yang telah terjadi di Sulawesi Tengah, di mana para pengungsi, mantan combatant, dan para aktivis kelas menengah di kota Palu selama bahu membahu memperlebar pendekatan psiko-sosial yang karitatif dengan advokasi anti-korupsi, sejajar dengan pemikiran Fanon. Perlawanan terhadap penindasan, dalam perspektif Fanon, merupakan satu-satunya terapi untuk keluar dari tekanan kejiwaan kaum tertindas. 
Pandangan popular tentang Fanon, hanyalah bahwa dia seorang "nabi pendukung kekerasan", sebagai anti-tesis dari Gandhi yang dianggap sebagai "nabi pendukung gerakan anti-kekerasan". Namun yang terpenting adalah melihat akar pemikiran Fanon, yang seperti Gandhi, Memmi dan Gramsci, melihat bahaya yang paling parah dari setiap bentuk penindasan adalah apabila sistem berfikir yang melatarbelakangi penindasan itu sudah diinternalisir oleh para korban. Dalam konteks konflik Poso dan Ambon, apabila para pengungsi dan mantan combatant, terus menginternalisir fikiran bahwa musuh mereka adalah orang-orang yang beragama berbeda dengan mereka. Khususnya, apabila permusuhan antara komunitas Muslim dan Nasrani, sudah dihayati secara mendalam oleh para korban konflik itu sendiri.

Karena itu, terjun ke dalam gerakan anti-korupsi dana kemanusiaan di Poso, dan bersama-sama memperjuangkan pembasmian korupsi di aras kabupaten, provinsi, dan nasional, dalam kacamata psikologi radikal Fanon, merupakan suatu bentuk terapi dari berbagai trauma yang diderita garagara konflik komunal yang lalu.

Sedangkan dari sudut kebudayaan, partisipasi para pengungsi dan mantan combatant dalamaksi-aksimassa secarabahumembahu, walaupun berbeda agama dan suku, dan bekerjasama dengan aktivis-aktivis berbasis kota dan kampus, dapat dilihat sebagai suatu inovasi budaya. Sebelumnya, masyarakat Poso sangat bersifat semi-feodal, di mana hanya para kabose (bangsawan) dapat menjadi jurubicara mereka. Baik kabose lama, maupun para 'kabose baru', yakni para pemuka agama - pendeta dan ulama - serta para pemimpin formal yang diangkat oleh pemerintah.

Terobosan yang paling Fanonian, adalah ketika sejumlah pemimpin desa dan kelurahan dari Kabupaten Poso, ikut berdemonstrasi di depan Istana Kepresidenan di Jakarta. Tapi justru di situlah oposisi dari jejaring korupsi terhadap gerakan anti-korupsi ini, yang didukung oleh Kapolda Sulawesi Tengah, Brigjen (Pol) Aryanto Sutadi, semakin menajam. Dugaan penulis, bom yang diledakkan di Pasar Tentena pada hari Sabtu pagi, 28 Mei yang lalu, yang mengakibatkan 22 orang meninggal dunia dan puluhan luka-luka, bermaksud antara lain menjegal gerakan anti-korupsi itu (lihat juga, Sangaji 2005).

KONTRWUSL PSIKOLOGI RADIKAL FRANTZ FANON 


\section{E. Kesimpulan}

Pengamatan terhadap kebutuhan pendampingan para korban konfiik Poso menunjukkan, bahwa pendekatan psiko-sosial yang hanya bersifat karitatif tidak cukup untuk memberdayakan penduduk untuk bangkit dari keterpurukannya, dan membangun kembali jaringan sosial masyarakat yang tercabik-cabik oleh konfiik komunal yang lalu. Psikologi radikal Frantz Fanon, menawarkan suatu pendekatan yang lebih menyeluruh, tanpa mengawetkan ketergantungan masyarakat korban pada badan-badan bantuan.

\section{DAFTAR PUSTAKA}

Aditjondro, George Junus (2000). Cahaya Bintang Kejora: Papua Barat dalam Kajian Sejarah. Budaya, Ekonomi. dan Hak Asasi Manusia. Jakarta: Elsam. Bab III ('Pembangunan Papua Barat Dalam Kerangka Analisis Fanon'), hal. 38-62.

(2004a) "Kayu Hitam, Bisnis Pos Penjagaan, Perdagangan Senjata dan Proteksi Modal Besar: Ekonomi Politik Bisnis Militer di Sulawesi Bagian Timur". Wacana. Jurnal Ilmu Sosial Transformatif, No. 17/Th. Ill, hal. 137-178.

(2004b). "Kerusuhan Poso dan Morowali, Akar Permasalahan dan Jalan Keluarnya." Dalam Dicky Mailoa, Jeirry

Sumampouw dan Teddy Weohau (peny.). Gereja-Gereja Menggumuli Konfiik dan Kekerasan Dalam Era Transisi Menuju Demokrasi di Indonesia: Prosiding Lokakarya Pengembangan Institusi dan Program Crisis Center PGI. Jakarta. 16-18 Januari 2004. Jakarta: Crisis Center PGI, hal. 171-216.

(2005). Anatomi Dampak Kerusuhan Poso: Pijakan untuk Agenda Perdamaian. Catatan untuk Consultation Meeting 'Refleksi \& Prospek Perdamaian di Indonesia' yang diselenggarakan di Hotel Seruni, Cisarua, 23-25 Februari oleh Pusat Bahasa \& Budaya, Universitas Islam Negeri Jakarta.

Elson, R.E. (2001). Soeharto: A Political Biography. Cambridge, U.K.: Cambridge University Press. 
Fanon, Frantz (1971). The Wretched of the Earth. Middlesex, U.K.: Penguin Books. Pertama kali diterbitkan dalam bahasa Perancis tahun 1961. Khususnya Bab 5: 'Colonial War and Mental Disorders', hal. 200250.

(1973). "The So-Called Dependendency Complex of Colonized People". Dalam Phil Brown (peny.). Radical Psychology. London: Tavistock Publications, hal. 257-285.

Gendzier, Irene L. (1974). Frantz Fanon: A Critical Study. New York: Pantheon Books. Khususnya Bagian II: 'Toward a Psychology of Colonial Relationships', 1953-1959, hal. 61-116.

Mannoni, Octave (1990). Prospero and Caliban: The Psychology of Colonization. Ann Arbor: The University of Michigan Press.

Sangaji, Arianto (2005). "Bom Tentena dan Korupsi", Kompas, 31 Mei. 


\title{
Biodata Singkat Penulis
}

\begin{abstract}
Abdul Kadir Ahmad, lahir di Gowa, 02 Juni 1956 adalah Kepala Balai Penelitian dan Pengembangan (Balitbang) Agama Makassar. Ia menyelesaikan program S2 jurusan Studi Pengelolaan Lingkungan Hidup pada Program Pasca Sarjana Universitas Hasanuddin Makassar, tahun 1990. Menyelesaikan program S3 pada Program Pasca Sarjana Universitas Hasanuddin Makassar, tahun 2005 dengan judul disertasi : Ulama Bugis dalam Dinamika Sosial di Sulawesi Selatan;Suatu Analisis Antropologi Agama. Saat ini ia juga tercatat sebagai dosen Progran Pasca Sarjana Universitas Muslim Indonesia (UMI) Makassar. Selain itu, juga tercatat sebagai Ketua Pengurus Cabang NU Kota Makassar dan Board of Director ECCF-RC Makassar.
\end{abstract}

M.Yamin Sani, lahir di Wajo pada tahun 1950 adalah tenaga pengajar pada Fakultas Ilmu Sosial dan Program Pascasarjana Universitas Hasanuddin. Beliau menyelesaikan S2 pada program Pascasarjana Universitas Airlangga dan sedang dalam proses penyelesaian doktoral pada program Pascasarjana Universitas. Selain sebagai tenaga pengajar, beliau juga merupakan konsultan penelitian di beberapa lembaga penelitian dan juga seorang penulis buku yang aktif.

Arifuddin Ismail, lahir di Majene, 29 Juni 1957 adalah peneliti pada Balai Litbang Agama Makassar. Ia menyelesaikan program S2 jurusan Antropologi pada Universitas Negeri Makassar tahun 2000. Pernah mengikuti Pusat Latihan Penelitian Ilmu-Ilmu Sosial (PLPIIS) di Universitas Syah Kuala, Banda Aceh tahun 1984-1958. Pernah menjadi Direktur Lembaga Kajian dan Pengembangan Masyarakat (LKPM) Makassar, periode tahun 19891994; Anggota Badan Musyawarah Forum Informasi dan Komunikasi (FIK) LSM Sulawesi Selatan tahun 1990-1994; Dewan Pembina Balai Latihan Pengembangan Masyarakat (BLPM) LAKSPESDAM Indonesia Timur, tahun 1991-2000; Dosen Luar Biasa Universitas Muslim Indonesia (UMI) Makassar,tahun 1983-1997; Tenaga Pelatih Lepas di Berbagai LSM dan Instansi Pemerintahan (terutama Depnaker dan Depag), tahun 1991sekarang. 
Pat. Badrun, lahir di Luwu Utara, 03 Desember 1942 adalah Ahli Peneliti Utama pada Balai Litbang Agama Makassar. Ia menyelesaikan pendidikan sarjananya (SI) di STIAN Ujungpandang 1979 dan Program S2 di IPB Bogor, tahun 1986; meingkuti Pusat Latihan Penelitian Ilmu-Umu Sosial (PLPIS) di Universitas Airlangga Surabaya tahun 1982-1983. Telah menghasilkan karya ilmiah berupa hasil penelitian yang ditulis sendiri maupun dengan penulis lain dalam bentuk buku, jurnal, majalah, dan surat kabar dalam tiga bidang kajian penelitian keagamaan, yakni: Bidang Pendidikan Agama, Bidang Agama dan Kemasyarakatan, serta (terutama) Bidang Lektur Keagamaan.

M. As'ad, lahir di Soppeng, 1952 adalah peneliti pada Balai Penelitian dan Pengembangan Agama Makassar. Ia menyelesaikan studi SI pada Fakultas Adab IAIN Alauddin Makassar tahun 1980. sekarang sedang dalam taraf penyelesaian S2 pada Program Pascasarjana Universitas Negeri Makassar. Pernah mengikuti Program Latihan Penelitian Ilmu-Ilmu Sosial (LPIIS) di Universitas Syiah Kuala, Banda Aceh (1984-1985); peserta Pelatihan Kemampuan Penelitian Keagamaan (PKPK) Angkatan XVI di Jakarta (1994) dan Angkatan XXI di Jakarta (1999).

Sirajuddin Ismail, lahir di Bima, Nusa Tenggara Barat, 16 September 1949 adalah peneliti pada Balai Litbang Agama Makassar. Ia menyelesaikan studi sarjananya (SI) pada Fakultas Tarbiyah IAIN Alauddin Ujungpandang, tahun 1980; menyelesaikan program S2 pada Program Pasca Sarjana Universitas Negeri Makassar Kekhususan Antropologi, tahun 2004. Telah melakukan beberapa penelitian keagamaan dari berbagai aspek. Hasil penelitian tersebut telah dipublikasi, baik dalam jurnal penelitian maupun penerbitan di Balai Litbang Agama Makassar.

Abubakar Tjaneng, dilahirkan di Barru 28 September 1944 adalah peneliti pada Balai Litbang Agama Makassar. Ia menyelesaikan Studi SI di IKIP Ujungpandang pada tahun 1979 dan menyelesaikan program studi S2 STIM (Sekolah Tinggi Ilmu Manajemen) Jakarta 1994. Selain bekerja sebagai peneliti, juga beraktivitas sebagai tenaga pengajar di beberapa universitas dan perguruan tinggi swasta di Kota Makassar. 
Abdul Kadir Massoweang, lahir di Sengkang, Wajo, 3 Mei 1956 adalah peneliti pada Balai Penelitian dan Pengembangan Makassar menyelesaikan pendidikan SI di Fakultas Adab Jurusan Bahasa Arab IAIN Alauddin Makassar tahun 1981. Menyelesaikan program pascasarjana di IAIN Alauddin Makassar tahun 1997 dan sedang melanjutkan pendidikan program doktoral pada Program Pascasarjana UIN Alauddin Makassar. Telah melakukan beberapa penelitian keagamaan dari berbagai aspek, hasil penelitian tersebut telah dipublikasikan baik dalam jurnal maupun penerbitan. Selain itu aktif sebagai mubaliq, guru dan dosen.

Goerge Yunus Aditjondro, lahir di Pekalongan, 27 Mei 1946 adalah seorang aktivis kemanusiaan yang sangatkritis mengkritisi kebijakan-kebijakan orde baru. Ia menyelesaikan pendidikan S2 pada tahun 1991: Master of Science, Cornell University, Ithaca, New York dan menyelesaikan pendidikan doctoral tahun 1993 di Universitas yang sama. Beliau merupakan penulis yang produktif, di antara karya tulisnya adalah: Puluhan buku, bab, kata pengantar, prolog dan epilog tentang Timor Leste, Papua, Aceh, Maluku, Sulawesi Tengah dan berbagai kelompok etno-linguistik (masyarakat adat) di Sulawesi dan Kalimantan, masalah lingkungan hidup, serta korupsi sistemik mantan Presiden Soeharto, yang diterbitkan dalam bahasa Indonesia dan Inggris. Segera terbit: Korupsi Kepresidenan: Reproduksi Oligarki Berkaki Tiga: Istana. Tangsi dan Partai Penguasa. oleh Lembaga Kajian Islam dan Sosial (LKiS), Yogyakarta 